\title{
Ownership and Control of Natural Resources under the Nigerian Constitution 1999 and Its Implications for Environmental Law and Practice
}

\author{
Theodore Okonkwo ${ }^{1}$ \\ ${ }^{1}$ Department of Public Law, Faculty of Law, University of Port-Harcourt, Port-Harcourt, Nigeria \\ Correspondence: Theodore Okonkwo, Department of Public Law, Faculty of Law, University of Port-Harcourt, \\ Port-Harcourt, Nigeria. E-mail: t161962@gmail.com
}

Received: Apirl 12, 2017

Accepted: April 26, 2017

Online Published: October 30, 2017

doi:10.5539/ilr.v6n1p162

URL: https://doi.org/10.5539/ilr.v6n1p162

\begin{abstract}
The right to ownership and control of natural resources under the Nigerian law is constitutional. The Constitution of the Federal Republic of Nigeria 1999 (as amended) section 44 (3) and item 39 Schedule II of the Exclusive Legislative List vests the control and management of the natural resources and hydrocarbon operations on the federal government for the common good and benefit of the citizens. This article aims at examining the constitutional provisions and its implications for environmental law and practice. It examines some theories of ownership of mineral resources and analyses the decisions of the Supreme Court of Nigeria on the subject, particularly the case of Attorney-General of the Federation v. Attorney General of Abia State \& 35 Others (No. 2) (2002) 6 NWLR (Part 764) 542 where the Supreme Court of Nigeria made several judicial pronouncements on the constitutional question of the derivation principle and ownership and control of natural resources in the Nigeria Federation. This article concludes by advocating for reforms and further research on the subject matter. It recommends the adoption of what is obtainable in other jurisdictions like Canada and South Africa.
\end{abstract}

Keywords: resource control, natural resources, constitution, environment, dichotomy, on-shore, off-shore, continental shelf

\section{Introduction}

Natural resources are raw materials that are extracted from the ground or soil. They are found naturally embedded in the soil and can only be modified by man for his benefit and use. The natural resource include fossil fuels, coal, oil, natural gas, gold, copper, iron, diamonds and minerals. Aladeitan, has described natural resources as "a gift of nature and an endowment of comfort that makes the existence of mankind complete". Since natural resources can be used to create and increase the wealth of a country, its ownership and control has become a subject of legal, political and socio-cultural controversy, for whoever controls them controls the environment. Thus, it is imperative that the wealth which is created through the ownership of natural resources must be distributed in such a manner that guarantees a reasonable share for the locality from which the natural resources are produced.

According to Sneh and Garg, ${ }^{2}$

Ownership is a complex juristic concept which has its origin in the Ancient Roman Law. In Roman Law Ownership and Possession were respectively termed dominium and possessio. The term dominium denotes absolute right to a thing while possessio implied only physical control over it. They gave more importance to ownership because in their opinion it is more important to have absolute right over a thing than to have physical control over it.

The ownership and control of natural resources is thus, very important to a country's wealth and well-being and

L Aladeitan, 'Ownership and Control of Oil, Gas, and Mineral Resources in Nigeria: Between Legality and Legitimacy' (2013) Thurgood Marshall Law Review, Vol. 38:159 at 160.

2 R Sneha and R Garg, 'Ownership' (2012). Lawyers in India; Law Articles available at http://www.legalserv.ceindia.com accessed (May 11, 2017). 
therefore cannot just be treated with levity. According to Salmond, ownership constitutes of a bundle of rights. ${ }^{3}$ Salmond's definition point out two characteristics of ownership: ownership is a relation between a person and right that is vested in him and ownership is incorporeal body or form (immaterial, having no material body or form). According to Austin, "ownership means a right which avails against everyone who is subject to the law conferring the right to put thing to user of infinite nature". He also defined full ownership as "a right indefinite in point of user, unrestricted in point of disposition and unlimited in point of duration".

The ownership regime of natural resource can also be ascertained from international conventions and customary international law, common law and national constitutions". This situation has given rise to the emergence of different theories of ownership and control of natural resources.

In Nigeria, the ownership and control of natural resources popularly termed "resource control" in terms of crude oil and the natural gas which are produced in the Niger Delta areas of the country has given rise to ethnic agitations and environmental terrorism "due partly to a sharp reaction by the oil producing communities, which suffer grievous hardships resulting from the operations of the laws governing the sector". ${ }^{4}$ These natural resources has been described as a curse to the people as the citizens continue to live in abject poverty with little or no development. ${ }^{5}$ The oil companies operating in these areas carry out hydrocarbon operations without due regard to the best international practices in the industry, thus, leaving trails of environmental destruction and human neglect. Within the Nigerian polity itself, ownership and control of the natural resources have equally generated crisis in the way and manner the financial proceeds are shared among the federating units of Nigeria in what is popularly known and called Revenue Allocation, which is tied to ownership and control of the natural resources. The concept of ownership is therefore very material on who controls the natural resources. For the purposes of this article, ownership connotes dominium, that is "complete power to use, to enjoy, and to dispose of property at will". This means that the legal right to own and control natural resources in Nigeria resides with the federal government which exercises "the maximum degree of formalized control over..." mines and minerals, including oil fields, oil mining, geological surveys, and natural gas and nuclear energy. ${ }^{6}$ Thus, ownership of natural resources as embedded in the Nigerian Constitution translates into "State Ownership", with the state granting leases of oil wells or oil fields to private companies for mining operations. This grant of mining leases to private companies gives them qualified ownership of the natural resources located within the area of the oil mining licence. ${ }^{7}$ This article in Part 2 takes a cursory look at the various theories of ownership of natural resources, Part 3 examines the ownership and control of natural resources under the Constitution of the Federal Republic of Nigeria 1999 (as amended). Part 4 looks at the issue of the principle of derivation of revenue allocation while Part 5 is a discussion of Supreme Court of Nigeria landmark case of Attorney-General of the Federation v. Attorney General of Abia State and 35 Others (No. 2). ${ }^{8}$ Part 6 is on what constitutes continental shelf and Part 7 is an examination of the implications for environmental law and practice of ownership and control of natural resources under the Constitution of the Federal Republic of Nigeria 1999 (as amended). Part 8 is the conclusion.

\section{Theories of Ownership of Natural Resources}

There are several theoretical concepts of ownership that govern the legal relationship and entitlements over natural resources. These concepts define the states' ownership and the individuals' ownership rights over natural resources. It has been stated that due to the fugacious nature of subsurface oil and gas the courts of the late 1800 's were presented with difficulties. For centuries, the legal maxim cujus est solum, ejus est usque ad coelom et ad inferos (the owner of the surface owns everything from the skies to the centre of the earth) has applied to ownership disputes. But due to the fugacious nature of oil and gas, a neighbour could drill a well on his side of the fence and drain away an owner's oil or gas. How could someone be said to own oil or gas unless he or the state could prevent the owner's loss. Then, as now, it is impossible to trace the oil and gas produced from a well so as to determine where it actually came from in the subsurface with any degree of certainty. This problem was

PJ Fitzgerald, Salmond on Jurisprudence 12th Edition (2013) Universal Law Pub Co. P. Ltd. Delhi pp. 504 at 256, 259.

FO Ayodele - Akaakar, 'Appraising the Oil and Gas Laws: A Search for Enduring Legislation for the Niger Delta Region' (2001), Journal of Sustainable Development in Africa, 3 (2) 1 - 27.

EG Burton, 'Reverse the Curse: Creating A Framework to Mitigate the Resource Curse and Promote Human Rights in Mineral Extraction Industries in Africa' (2014). Emory Int'l L. Rev. 28 at 425.

$6 \quad$ Items 39 and 41, Schedule II, Exclusive Legislative List (ELL), Constitution of the Federal Republic of Nigeria.

PH Martin and BM Kramer, Oil and Gas Law (2012). William and Meyers at 202.

MA Ajomo, 'The Legal Framework of the Petroleum Industry' (2001). Paper presented at the Centre for Petroleum Environment and Development Studies Workshop on Essentials of Oil and Gas Law, Lagos, Nigeria. 
especially acute in the United States because the 14th Amendment in the American Constitution specifically protects private property. ${ }^{9}$ This article examines some of these theories.

\subsection{Absolute Ownership Theory}

This theory declares that whoever owns a piece of land owns the natural resources lying of underneath it. Absolute ownership has been defined as "the actual right a person is having on a property. A property in actual ownership can be freely transferable and inheritable". Land includes the right to minerals underneath and the airspace over it. The definition of "absolute ownership" can be expressed in the Latin maxim quic quid plantatur, solo solo cedit (whatever is affixed to the soil belongs to the soil). This is only a general statement of the law. This is so, because in some jurisdictions like Nigeria, though title to land vests in the Governor of each state, the natural resources which by definition is part of the land does not belong to the state but vests in the federal government. The federal government absolutely owns the minerals. ${ }^{10}$ Another Latin maxim that explains this theory is cojus est solum, ejus est usque ad coelom ad inferos, which means "to whomever the soil belongs he owns also the sky and to the depth". Again, this principle is limited to a certain extent as the advent of air and space travel have placed a limitation on the application of this theory.

According to Aladeitan, "the implication of the ownership in place theory is that the land owner owned the land and the resources beneath his land absolutely and could confer separate titles to them by reservation, separation, or severance". ${ }^{11}$

Nigeria's Petroleum Act codifies this theory by stating that "the entire ownership and control of all petroleum in, under, or upon any lands to which this section applies shall be vested in the state". ${ }^{12}$ Therefore, in Nigeria natural resources is absolutely owned by the state. The theory of "ownership-in-place" was first adopted in the U.S. state of Texas in respect of ownership of oil and gas, "that a landowner owns a corporeal possessory interest (similar to a fee simple) in the substances beneath his land, but his ownership is a determinable fee subject to the rule of capture". ${ }^{13}$ The theory was given judicial backing in a leading case where the court stated that:

Oil and gas in place are minerals and realty subject to ownership, severance, and sale while embedded in the sands and rocks beneath the earth's surface in like manner and to the same extent as is coal or any other solid minerals. ${ }^{14}$

One of the leading cases for the ownership in place theory, as it is applied in Texas is Brown v. Humble Oil \& Refining Co. ${ }^{15}$ where the Court stated:

Owing to the peculiar characteristics of oil and gas, the foregoing rule of ownership of oil and gas in place should be considered in connection with the law of capture. This rule gives the right to produce all of the oil and gas that will flow out of the well of one's land and this is a property right. And it is limited only by the physical possibility of the adjoining landowner's diminishing the oil and gas under one's land by the exercise of the same right of capture. (emphasis added)

\subsection{The Qualified Ownership Theory}

This theory states that minerals, that is, oil and gas are incapable of being owned, until they are captured and reduced into possession. This theory means that non-absolute property inheres in a person. The ownership is limited in time, restricted to one or more uses, or shared. ${ }^{16}$ In our context, it is simply the theory that minerals such as oil and gas cannot be owned in place before they are extracted and reduced to possession. In qualified ownership jurisdictions, what the mineral owner owns is the exclusive right to reduce the oil or gas to possession.

\footnotetext{
9 'About 'Owning' Petroleum and atural able http://www.fhoa.ca/about-freehold-mineral-rights/about-owning-petroleum-a-natural-gass.html (accessed May 13, 2017).

10 Section 44(3) and item 39 Constitution of the Federal Republic of Nigeria, 1999 (as amended).

Ibid.

Section 1, Petroleum Act, Cap. P10 Laws of the Federation of Nigeria 2004, Vol. 13. See also, section 44 (3) and item 39 Constitution of the Federal Republic of Nigeria, 1999 (as amended).

13 Other states, like Oklahoma, have adopted the 'exclusive-right-to-take' theory that a landowner does not own the substances that underlie his land, but merely retains the exclusive right to capture the substances, a non-corporeal interest'.

14 Stephen County v. Mid-Kansas Oil \& Gas Co. (1923) 113 Tex. 160, 167, 254 S. W. 290, 292.

(1935) Tex. S. C. 83 S. W. (2d) 935 at 940.

Holmes v. United States, 85 F. 3d 956, 959 (2d Cir. 1996).
} 
Thus, this theory "does not accept that full ownership can be vested in oil and gas in situ". ${ }^{17}$ Clark has described this theory as "proprietary right [that] is analogous with a profit à prendre under English common law or a servitude right to minerals under Scots law". ${ }^{18}$

The qualified theory has also been referred to by some courts and writers as the "law of capture". This article argues that under the Nigerian Land Use Act, ${ }^{19}$ the oil producing communities only own "surface rights", they do not have right of access to the oil and gas. Where there are minerals and other natural resources underneath the soil, the federal government acquires the land and pays compensation.

As far back as 1900, the qualified ownership theory received judicial support in the case of Manufacturers' Gas \& Oil Co. v. Indiana Natural Gas \& Oil Co. ${ }^{20}$ In this case, the defendant used pumps to increase the natural flow of gas from its wells in violation of an Indiana statute. ${ }^{21}$ It was proved that the practice would be injurious to the reservoir and the court held that the plaintiffs, who owned other land in the reservoir, were entitled to an injunction to halt the practice. The United States Supreme Court stated the differences between natural gas and underground water. While pronouncing on the property rights of the plaintiffs in the natural gas, it said:

Without the consent of the owner of the land, the public cannot appropriate it, use it, or enjoy any benefit whatever from it. This power of the owner of the land to exclude the public from its use and enjoyment plainly distinguishes it from all other things with which it has been compared, in the use, enjoyment and control of which the public has the right to participate, and tends to impress upon it, even when in the ground in its natural state, at least, in a qualified degree, one of the characteristics or attributes of private property. ${ }^{22}$

The leading case for qualified ownership as it is applied in Oklahoma, is Rich v. Donaghey ${ }^{23}$ where the Court, citing the Supreme Court decision in Ohio Oil, stated that fee simple owners of land have:

...no absolute right or title to the oil or gas which might permeate the strata underlying the surface of their land, as in the case of coal or other solid minerals fixed in, and forming part of, the soil itself.

But with respect to such oil and gas, they had certain rights designated by the same courts as a qualified ownership thereof, but which may be more accurately stated as exclusive right, subject to legislative control against waste and the like, to erect structures on the surface of their land, and explore thereof by drilling wells through the underlying strata, and to take therefrom and reduce to possession, and thus acquire absolute title as personal property to such as might be found and obtained thereby. This right is the proper subject of sale and may be granted or reserved. This right so granted or reserved, and held separate and apart from the possession of the land itself, is an incorporeal hereditament; or more specifically, as designated in the ancient French, a profit à prendre,... (emphasis added).

According to Woodward, "under this theory the owner of the land can have no "title" to the oil and gas in place, but he does have the exclusive right to drill and produce from his own tract and to become the owner of the product when it is brought up to the surface". ${ }^{24}$

\subsection{The Non-Ownership Theory}

In the context of oil and gas, non-ownership theory has been defined as "a characterisation of oil and gas rights used in a minority of jurisdictions [in the United States]. This theory holds that the owner of a severed mineral interest does not have a present right to possess the oil and gas in place, but... has the right only to search for, develop, and produce it". ${ }^{25}$

The Supreme Court of Pennsylvania in the case of Westmoreland and Cambria Natural Gas Co. v. De Witt et

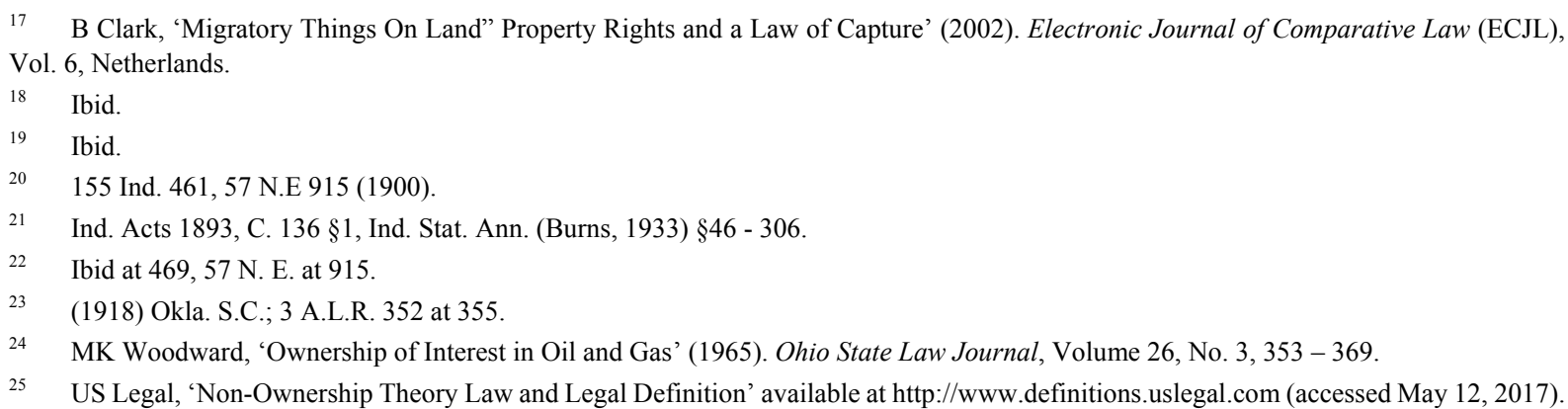


$a l,{ }^{26}$ declared support for this theory in the following words:

Natural gas belongs to the owner of the land, and is part of it, and, so long as it is on or in it, is subject to his control; but when it escapes, and goes into other land, or comes under another's control, the title of the former owner is gone.

If an adjoining or distant owner drills a well on his own land and taps his neighbour's vein of gas, so that it comes into his well and under his control, such gas belongs to the owner of the well. The owner of land, leasing it to another for the purpose of drilling gas wells thereon, and reserving the right to till the soil, after the lessee has drilled a well and has gas ready to flow into pipes by turning a valve, cannot claim that the lessee is not in possession, and that he must resort to a court of law to establish his title before a court of equity will interfere...

The court describes gas as ferae naturae "in common with animals, and unlike other minerals, they have the power and the tendency to escape without the volition of the owner. Their fugitive and wandering existence within the limits of a particular tract was uncertain". ${ }^{27}$ The court stated that "possession of the land, therefore, is not necessarily possession of the gas". ${ }^{28}$

In State v. Ohio Oil Co. ${ }^{29}$ the non-ownership theory was re-affirmed by the court:

To say that the title to natural gas vests in the owner of the land, in, or under which it exists today, and that tomorrow, having passed into or under the land of an adjoining owner, it thereby becomes [the property of that adjoining owner], is no less absurd, and contrary to all the analogies of the law, than to say that wild animals or fowls, in 'their fugitive and wandering existence', in passing over the land, become the property of the owner of such land, or that fish, in their passage up or down a stream of water, become the property of each successive owner over whose land the stream passes. [Hence, the court reasoned that to hold otherwise will be] as unreasonable and untenable as to say that the air and the sunshine which float over the owner's land is a part of the land, and is the property of the owner of the land. [The Court] therefore [held] that the title to natural gas does not vest in any private owner until it is reduced to actual possession. ${ }^{30}$

In the case of Kelly v. Ohio Oil Co. ${ }^{31}$ the non-ownership theory was further upheld by the court. The court stated that:

Whatever gets into the well belongs to the owner of the well no matter where it came from. In such cases, the well and its contents belong to the owner or lessee of the land, and no one can tell to a certainty from whence the oil, gas or water which enters the well came, and no legal right as to the same can be established or enforced by an adjoining landowner. ${ }^{32}$

In 1900, the United States Supreme Court in the case of Ohio Oil Co. v. Indiana ${ }^{33}$ enunciated what has come to be known as the 'non-ownership' or 'qualified ownership theory of oil and gas law:

Although in virtue of his proprietorship the owner of the surface may bore wells for the purpose of extracting natural gas and oil, until these substances are actually reduced by him to possession, he has no title whatever to them as owner. That is, he has the exclusive right on his own land to seek to acquire them, but they do not become his property until the effort has resulted in dominion and control by actual possession.

Woodward ${ }^{34}$ has argued that "several writers have classified Ohio as an absolute ownership state on the basis of expressions found in Kelley v. Ohio Oil Co., ${ }^{35}$ and two later cases". ${ }^{36}$ According to him "...the Kelley case

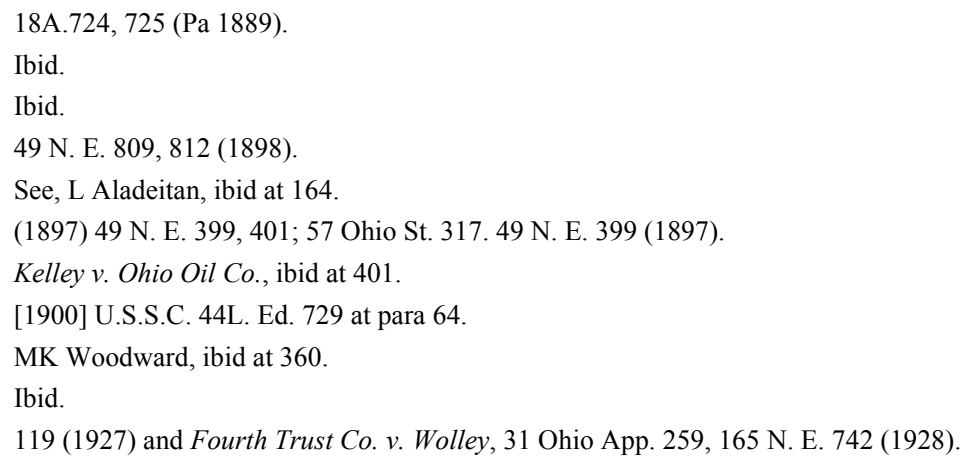


contains language which would support either [absolute or qualified] theory". The court stated that:

Petroleum oil is a mineral, and while in the earth it is part of the realty and should it move from place to place by percolation or otherwise, it forms part of that tract of land in which it tarries for the time being...

The court went further to state, "that when oil is brought to the surface":

...then for the first time it becomes the subject of distinct ownership separate from the realty, and becomes personal property, the property of the person into whose well it came. ${ }^{37}$

One of the leading authorities for non-ownership as it is applied in Louisiana, is Strother v. Mangham ${ }^{38}$ where the Court stated:

The doctrine that the owner of the land has no property right in the oil and gas beneath the surface until he has reduced it to possession in no manner denies to such owner the exclusive right to the use of the surface for the purposes of such reduction, or for any other purpose not prohibited by law, but, to the contrary, concedes that right, as inherent in the title to the land, and subject only to the control of the state, in the exercise of its police power; and the right may be sold, as may any other right, and may carry with it the right to the oil and gas that may be found and reduced to possession. (emphasis added)

The principle that oil and gas cannot be owned absolutely until found and reduced to possession is recognized in all of the oil and gas producing jurisdictions of the United States. This principle was incorporated into Canadian oil and gas law by the 1953 decision of the Judicial Committee of the Privy Council in Borys v. CPR and Imperial Oil Limited ${ }^{39}$ where Lord Porter, for the Privy Council, stated:

The substance are fugacious and are not stable within the container although they cannot escape from it. If any of the three substances (petroleum, gas or water) is withdrawn from a portion of the property which does not belong to the appellant but lies within the same container and any oil or gas situated in his property thereby filters from it to the surrounding lands, admittedly he has no remedy. So, also, if any substance is withdrawn from his property, thereby causing any fugacious matter to enter his land, the surrounding owners have no remedy against him. The only safeguard is to be the first to get to work, in which case, those who make the recovery become owners of the material which they withdraw for any well which is situated on their property or from which they have authority to draw. (Emphasis added)

In Anderson v. Amoco, ${ }^{40}$ where owners of split title natural gas asserted that oil and gas ownership theory prevented petroleum from being owned until it was reduced to possession, Justice Jack Major, for the unanimous Supreme Court of Canada, had this to say:

This is the type of broad ownership theory that is not required to be determined in this appeal. Irrespective of any other rights the parties may have in relation to the hydrocarbons in the ground, they chose to divide their interest by contract. It is not open to later argue that division was meaningless on the basis that no rights can attach until the substance is reduced to possession. When the substance, which was not in their possession at the time of the contract, is reduced to possession, the date and terms of the contract govern their relative entitlement.

This article argues that the question of non-ownership theory is not settled by the case of Kelley v. Ohio Oil Co., it can be either absolute, qualified, or neither. The case of Frost-Johnson Lumber Co. v. Sailing's Heirs ${ }^{4 I}$ also determined that because oil and gas migrate from place to place beneath the surface it is incapable of being owned. The court reasoned that the "only right regarding minerals inherent in title to land was that of exploring for oil and gas and reducing them to possession and ownership." ${ }^{42}$

This article argues that there are many reasons why the non-ownership theory could no longer stand the test of time. First is that modern scientific technology has defeated the theory, though oil and gas move from one place to the other, it is presently capable of ownership by an individual, corporate entities or government. Second, the concept that oil and gas are migratory, though on the face of it is true, but this is limited to the extent that when

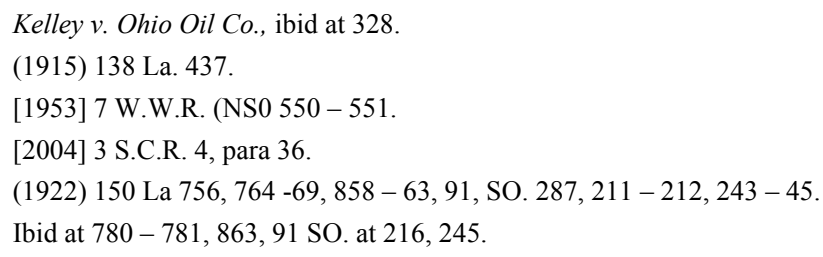


oil and gas eventually reach "a trap", they remain "relatively static until the reservoir is tapped"43 therefore, the "judicial thought" expressed in the cases discussed above, becomes unhelpful in modern century. Hardy had earlier on argued this point when he wrote that "for this reason, the concept of free migration or self-transmission can be considered erroneous in so far as it forms the basic premise for the non-ownership theory and the servitude analogy". ${ }^{4}$

\subsection{Ownership of Strata Theory}

This theory states that "the landowner owns the sedimentary layer containing the oil and gas within the limits of the vertical planes representing the boundaries of his tract". This theory creates limited ownership of oil and gas.

\subsection{Servitude Theory (Profit à Prendre)}

This theory declares that the owner has an exclusive right to remove the minerals. This exclusive right is referred to as "servitude". In this case, the minerals are not possessed by the owner prior to removal, thus they are not capable of possession by anyone prior to removal. Generally, this theory "applies equally to situations of complete or severed ownership". However, it must be pointed out that judicial pronouncements that a surface owner who is in actual possession of the surface is in constructive possession of the minerals in place has "muddied" this theory. ${ }^{45}$ According to Smith, "when there is a severance, the mineral owner has a profit à prendre", which in the United States Law "is treated the same as an easement for most purposes... the profit is in gross, meaning that its ownership is not tied to the ownership of other land in the vicinity (i.e. to a dominant estate)".

Finally, it should be noted that the modern concepts of "state ownership" and "private ownership" of natural resources has been greatly influenced by either of the above theories of ownership of natural resources, and these has become "the basis of the legal system and concept of property rights adopted by different countries across the world in the regulation, use, management, transfer and alienation of their natural resource endowment" ${ }^{46}$

\section{Ownership and Control of Natural Resources}

The ownership and control of natural resources in Nigeria pre-dates the Constitution of the Federal Republic of Nigeria 1999 (as amended). Prior to Nigeria's independence, the country and its natural resources were regarded as the property of the Great Britain.47 The British people laid claim to and controlled the natural resources found in Nigeria without "the interest of the colonised people.48 British colonial administration enacted oil and mining regulations which vested mineral rights in Nigeria on the British government.49 In 1914, Lord Lugard, enacted the Mineral Oil Ordinance "to secure easy administration over mining and oil rights ... and making it a wholly British concern".50 The 1914 Mineral Oil Ordinance provides that:

No lease or license shall be granted except to a British subject or to a British company registered in Great Britain or in a British colony and having its principal place of business within her majesty's dominion, the chairman and managing director (if any) and the majority of the directors of which are British subjects. ${ }^{51}$

Commenting on this provision, Okonmah has written that this piece of legislation "vested the right to search for, win and work mineral oils exclusively in British subjects or companies controlled by them". Simply put, this statute entrusted on Lord Lugard the power to exclusively grant "sole concessionary rights over mining and oil... only to British companies and subjects..."

According to Schatzl, the 1914 Mineral Oils Ordinance empowered the company to:

\footnotetext{
43 GW Hardy III, 'Public Policy and Terminability of Mineral Rights in Louisiana' (1966). Louisiana Law Review, Volume 26 Number 4, at 734.

$44 \quad$ Ibid at 734 .

45 JC Smith, 'Ownership and Use of Subterranean Space' available at https://www.emlf.org (accessed on May 12, 2017).

$46 \quad$ L Aladeitan, ibid at 167.

47 I Sagay, 'Ownership and Control of Nigerian Petroleum Resources: A Legal Angle', (1997) Nigerian Petroleum Business: A Handbook (Victor Erostosele, ed.) at $\mathrm{p} 8$.

48 In 1906 and 1907, Legal Guidelines on mining were enacted to govern the operations of the mining and oil companies in Nigeria. In 1914 Lord Lugard enacted the Mineral Oils Ordinance.

49 AOY Raji and TS Abejide, 'The British Mining and Oil Regulations in Colonial Nigeria C. 1914 - 1960s: An Assessment', (2014). Singaporean Journal of Business Economics and Management Studies, Volume 2, No. 10 at $63-66$.

50 Section 6 (1), 1914 Mineral Oils Ordinance, Laws of the Federation of Nigeria and Lagos (In Force 1 June, 1958 (1959)).

51 PO Okonmah, 'Rights to Clean Environment" The Case for the People of Oil-Producing Communities in the Niger Delta', (1997) Journal of African Law, 4 (1) at $43-67$.
} 
...at all reasonable times to enter into and upon any part of leased area for all or any of the following purposes: (a) to examine boreholes, wells, chattels, plant, appliances, buildings, installations, works and effects used for the operation... (b) to inspect the samples of strata, petroleum or water which the lease is required to keep in accordance with the provision of the lease... ${ }^{52}$

This statute failed to recognize the interest of Nigerians. The Minerals Ordinance $1916^{53}$ provides that: ${ }^{54}$

The entire property in and control of the minerals, and mineral oils, in, under or upon any land in Nigeria, and of all rivers, streams and water courses, throughout Nigeria, is and shall be vested in the crown, save in so far as such rights may in any case have been limited by express grant made before the commencement of this Ordinance. ${ }^{55}$

The 1916 Mineral Ordinance made provisions for mining rights ${ }^{56}$ and payment of compensation "to the owner of any building, or of any economic trees, or crops removed, destroyed or damaged by the lessee, his agents workmen: provided that compensation shall not be payable in respect of any building erected or trees or crops planted on land in respect of which surface rent is paid by the lessee under section 32 after the date of which such rent commences to be payable". ${ }^{57}$

These statutes reflect the colonial and oppressive minds of the British imperialists who were only interested in protecting their own selfish interests without considering that of the natives.

The Minerals Act of $1958^{58}$ made express provision for the exploration of petroleum from the territorial waters and the continental shelf of Nigeria and to vest the ownership of, and all on-shore and off-shore revenue from petroleum resources derivable therefrom in the Federal Government and for all other matters incidental thereto. ${ }^{59}$ In the words of the Act:

(1) The entire ownership and control of all petroleum in, under, or upon any lands to which this section applies shall be vested in the state.

(2) This section applies to all land (including land covered by water) which -

(a) is in Nigeria; or

(b) is under the territorial waters of Nigeria; or

(c) forms part of the continental shelfs; or

(d) forms part of the Exclusive Economic Zone of Nigeria.

(3) In this section references to "territorial waters" are references to the expression as defined in the Territorial Waters Act.

The Nigeria 1979 Constitution provides that the federal government has exclusive ownership of oil and solid mineral resources, but requires it to pay a minimum of 13 per cent of the revenue accruable to the Federation Account from natural resources extracted from the oil producing states to that state. The Constitution states that this derivation principle "shall be constantly reflected in any approved formula". ${ }^{60}$ The issue of revenue allocation which is tied to the ownership and control of natural resources by virtue of the provisions of the Constitution of the Federal Republic of Nigeria 1999 (as amended) has been judicially determined, ${ }^{61}$ though the case was eventually settled politically with the country's National Assembly abolishing the on-shore and

\footnotetext{
52 LH Schatzl, Petroleum in Nigeria (1969), Ibadan: Oxford University Press at 78.

53 Annual Report of the Colonies, Nigeria 1916, No. 946.

$54 \quad$ Section 3 (1), ibid.

55 See sections 22 and 34 (1) of the 1916 Mineral Ordinance on mining rights.

6 Section 22 , ibid.

57 Section 34 (1), ibid.

58 Commencement date, 27th November, 1969 Petroleum Act 1969. Now Cap. P10 Laws of the Federation of Nigeria 2004, Volume 13.

Section 1, ibid.

60 The 1960 Constitution provided for 100 per cent, while the 1963 Constitution provided for 50 per cent payable to the regions from where the natural resources were extracted. A recent attempt by the federal government to deprive the littoral states of revenue from the off-shore natural resources based on the derivation principle was the main subject of litigation in the case of Attorney-General of the Federation $v$. Attorney-General of Abia State and 35 Others (2001) 11 NWLR 689, where the Supreme Court of Nigeria extensively discussed the provisions of the Petroleum Act 1969; the Territorial Waters Act, the 1979 and 1999 Constitutions of the Federal Republic of Nigeria. The case also raised the issues of Exclusive Economic Zone Act and the United Nations Law of the Sea, 1982.

61 Ibid, footnote 60 , above.
} 
off-shore dichotomy as applied in the sharing of revenues accruing to the oil producing states. The extant statutes regulating the ownership and control of natural resources in Nigeria are, the Constitution of the Federal Republic of Nigeria 1999 (as amended); ${ }^{62}$ the Land Use Act $1978 ;{ }^{63}$ Nigerian Minerals and Mining Act 2007; ${ }^{64}$ and the Petroleum Act. ${ }^{65}$

The Constitution of the Federal Republic of Nigeria 1999 (as amended) vests the ownership and control of natural resources on the federal government. Section $44(3)^{66}$ provides that:

Notwithstanding the foregoing provision of this section, the entire property in and control of all minerals, mineral oils and natural gas in, under or upon any land in Nigeria or in, under or upon territorial waters and the Economic Zone of Nigeria shall vest in the Government of the Federation and shall be managed in such manner as may be prescribed by the National Assembly.

Furthermore, the Constitution provides that mines and minerals, including oil fields, oil mining, geological surveys and natural gas are the exclusive preserve of the federal government of Nigeria. ${ }^{67}$ The exclusivity of this provision as in that of the 1963 and 1979 Constitutions represent a reflection of British colonial statutes in Nigeria that vested ownership and control of natural resources on the Crown, while granting oil exploration and mining rights and prospecting licences to corporate entities. The Petroleum Act $1969^{68}$ pursued the same concept that ownership and control of "all on-shore and off-shore revenue from the territorial waters and the continental shelf of Nigeria and petroleum resources derivable therefrom [vest] in the Federal Government..."69

The Nigeria Minerals and Mining Act ${ }^{70}$ which repealed the Minerals and Mining Act of 1999 provides that:

The entire property in and control of all mineral resources in, under or upon any land in Nigeria, its continuous continental shelf and all rivers, streams and water courses throughout Nigeria, any area covered by its territorial waters or constituency and the Exclusive Economic Zones is and shall be vested in the Government of the Federation for and on behalf of the people of Nigeria. ${ }^{71}$

The Land Use $\mathrm{Act}^{72}$ vests all land comprised in the territory of each State (except land vested in the Federal Government or its agencies) solely in the Governor of the State, who hold such land in trust for the people and would be responsible for allocation of land in all urban areas to individuals. ${ }^{73}$ Thus, though title to land vests in the Governor, he cannot lay claim to lands which belong to the federal government and its agencies. ${ }^{74}$ The Governor cannot also lay claim to lands that contain natural resources, neither can he "have any direct control over the exploration and exploitation of minerals". 75

The issue of ownership and control of natural resources throws up the question of the legitimateness or constitutionality of the concept. This article has attempted to argue the issue, but gaps and limitations still remain, which hopefully will be addressed in future research. Despite the constitutional and statutory legislations which vest ownership and control of natural resources in the federal government, the debate on "resource control" persists and continue to be contemporary topic with various legal opinions on where true ownership and control of natural resources resides. The Niger Delta people remain aggrieved and maintain that the land and natural

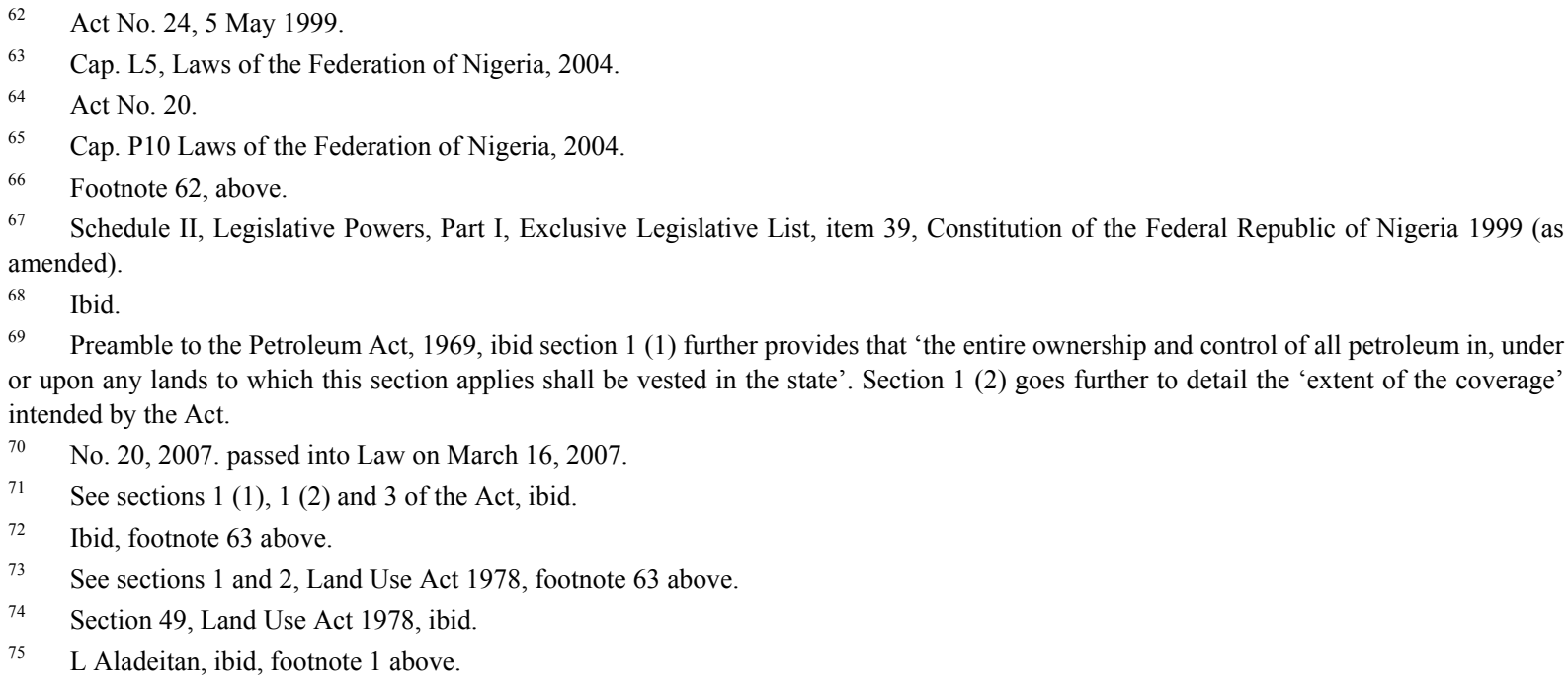


resources that are situate "within the Ijaw territory belong to the Ijaw communities and are the basis of our survival". ${ }^{76}$ The Kaima Declaration further declares, that the Ijaw nation "cease to recognise all undemocratic decrees that rob our peoples/communities of the right to ownership and control of our lives and resources, which were enacted without our participation and consent. These include, the Land Use Decree and the Petroleum Decree". ${ }^{77}$

Given the above scenario, what keep on resonating in the littoral states is the demand for resource control, that is, "acquiring political power over resource production, management and utilization in the area of location to ensure regeneration of the environment and over all sustainable development of the people." ${ }^{, 78}$ Therefore, this article argues that a very proactive and enduring constitutional approach is needed in order to accommodate the legitimate expectation of the littoral states. Fiscal federalism appears to be the solution. There should be a constitutional inclusion of a holistic and transparent "broader public finance discipline" in terms of division of governmental functions and financial relations among the levels of federating units of the Federal Republic of Nigeria. In this way the littoral states will feel involved in the Nigerian project. The frustration has continued leading to the ongoing rise in militancy that destroys oil installations in the Niger Delta. This situation was captured by a public commentator in the following words:

There is a great sense of frustration on the part of the states in that there is a very large mis-match between the requirements of the states to supply services in a whole variety of areas for their citizens and the lack of necessary resources to adequately meet the requirements, it is absolutely necessary and important to balance the powers, responsibilities and the financial resources at this level of government. Some of these may involve constitutional issues. There is the need for and in fact, there should be an administrative arrangement between levels of government. Canada, for instance, after sixty years of confederation, eventually transferred the authority for natural resources from the federal government to the provinces - confederation in 1867; resource control, 1931. As time went on the people realized the need for bringing resources in the hands of the provinces and that the provinces, too, perhaps would do a better job of managing those resources. Another area of consensus is that a federation is a dynamic institution. It is not something that is static; it has to evolve with time and it has to be responsive to the needs of the people. ${ }^{79}$

The position in South Africa and the United States are not different, as the people had gone through the same experiences as Nigeria, in the past. The implication for environmental law of the federal government ownership and control of natural resources is that it leaves the littoral states with less funds to combat the hazards posed to their environment by virtue of the exploration and exploitation of the natural resources. The decision of the federal government to revisit the issue of off-shore/on-shore oil dichotomy and the response of the National Assembly in passing the Off-shore/On-shore Oil Dichotomy Abrogation Bill, abolishing the dichotomy would enable the eight littoral states of Akwa-Ibom, Bayelsa, Cross-River, Delta, Lagos, Ogun, Ondo and Rivers to benefit from the revenue accruable from off-shore in all the contiguous zone within the state(s) that adjoins such sea. With more revenue accruable to them, the littoral states would be better positioned to advance, safeguard and protect the developmental needs and environmental rights of their citizens, thus enhancing co-ordinated management and protection of the environment. The littoral states presently maintain that they want full control of the natural resources located in their area. According to Professor Itse Sagay:

... Our paramount condition for continued willing participation in the on-going Nigerian project must be the total ownership and control by the people of the South South of their God-given natural resources, or at the very last, (sic) a resort to the provisions of the 1960 constitution on revenue allocation, particularly the process of mineral resources. As an instrument for the peaceful realization of these legitimate objectives, and the recovery of ownership of the resources seized from them by the powerful majority groups the South South should support the convening of a National Conference to discuss the basis of future political, economic and social association and co-existence between the ethnic nationalities of this country. ${ }^{80}$

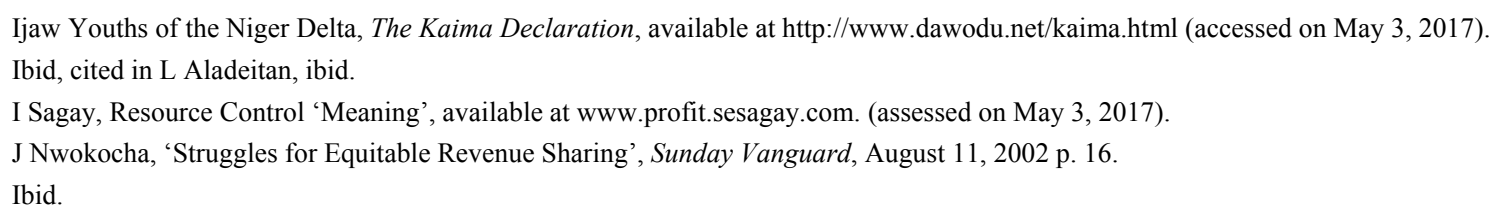


In view of the foregoing, this article argues that not just the littoral states, but each federating unit of the federal republic should be constitutionally allowed to make laws that will govern the hydrocarbon operations, exploitation and production of the natural resources just as is obtained in Canada, South Africa and he United States. Private ownership of land and natural resources located in them should be permitted with inbuilt mechanisms to check abuse and corruption. A landowner should be granted exclusive right to carry out oil drilling operations of natural resources contained in his land. The federal government should limit its interest to taxes, land lease bonuses, royalties and rentals. This is the position in the United States where "private property rights are firmly entrenched". ${ }^{81}$ In principle, natural resources located on private land remain the property of the landowner "if there are no supervening issues". In practice however, many land Ownership Agreements "exclude mineral rights, which an earlier landowner has sold to someone else". In the United States, natural resources located "on federal land are held in trust by the government and may be exploited if Congress permits". Nigeria should adopt the United States' approach, mostly as both operate the federal system of government, the former having borrowed it from the later.

Writing on resource rights in Canada's federal system, Andrew Thompson has stated as follows:

The right to develop resources (or to choose not to develop them) is, in the first instance, a right of ownership. Under the common law of Canada, the basic rule is that the ownership of land carries with it the right to harvest renewable resources such as crops, trees, fish and wildlife, and also the right to extract non-renewable resources such as coal, minerals and oil. Originally, governments in Canada gave individuals ownership of this type when crown land grants were made to settlers and developers, but new policies emerged around the turn of the century whereby governments gave only restricted ownership rights to resource developers. Mining leases and limited cutting rights began to replace outright grant of mineral and forest lands. In the case of agricultural lands, homesteaders of crown grants did not include rights to minerals such as coal, oil and gas under their land. The government retained ownership of minerals and gave only restricted development rights (by means of leases) to companies conducting exploration for minerals such as petroleum and natural gas.

Under the Constitution Act, 1867, the original provinces of Confederation retained ownership of crown lands and resources within their boundaries. When BC and PEI joined Confederation in 1871 and 1873, they too retained ownership of natural resources. But when the Prairie provinces were created (Manitoba in 1870, Alberta and Saskatchewan in 1905) a new and controversial policy emerged. In these provinces, ownership of natural resources was retained by the federal government to provide funds for colonization and railway building. Not until 1930, after a sometimes bitter political struggle, were natural-resource rights transferred by the federal government to Prairie provinces. By this time, most of the agricultural lands had been transferred into private ownership; but because the federal government had reserved mineral rights when disposing of land in the Prairies and had granted restricted tenures, the provincial governments inherited a rich treasure house of resource rights under the 1930 transfer. It is as a consequence of these rights that Alberta grants oil and gas leases and receives oil and gas royalties; that Manitoba can develop vast hydroelectric power resource to sell in the US; and that Saskatchewan controls uranium and potash reserves of worldwide significance.

The mineral and petroleum resources of northern Canada and the offshore regions of the East and West coasts remain under the ownership and control of the federal government and provide a huge potential for development. The federal government has also passed legislation that provides for the issuing of exploration rights and production licenses, under which developers must meet expenditure commitments and pay royalties should commercial production begin. The Canada Oil and Gas Act, 1880-81-82, established a federal regime for petroleum resources that was intended to increase Canadian ownership in petroleum companies and to ensure Canadian benefits in jobs and the procurement of goods and services. With the change of government, in 1985 this statute was replaced by the Canada Petroleum Resources Act, with less emphasis on these "Canadianization" issues and greater certainty in the terms and conditions of exploration and development. Canada is a large country with

\footnotetext{
81 See the Executive Order 9633, of September 28 1945, Federal Register 10FR 12305, October 2, 1945 reserving and placing certain resources of the continental shelf under the control and jurisdiction of the Secretary of the Interior. This was revoked by EO 10426, January, 1953.
} 
bountiful natural resources. Its size and its federal system of government explain why natural resources play such an important role in the Canadian economy and why government policies are so significant and so likely to be contentious. In these circumstances, it is a continuing national challenge to manage natural resources co-operatively and wisely. ${ }^{82}$

In the United Kingdom, there abound a variety of natural resources, coal, petroleum, natural gas, limestone; chalk, gypsum, silica, rock salt, china clay, iron ore, tin, silver, gold, lead and others. ${ }^{83}$ With the exception of oil, natural gas, coal, gold and silver the United Kingdom government does not own mineral rights in principle, minerals are held in private ownership in the United Kingdom. The ownership of oil and gas in the United Kingdom was vested in the Crown by the Petroleum (Production) Act 1934, now repealed by the Petroleum Act of 1998 which vests exclusive rights to exploit and develop oil and gas onshore with the United Kingdom government, the Crown. The United Kingdom Continental Shelf Act, 1964 vests ownership of the natural resources in the Crown. This consists of areas located within and beneath the seabed, beyond territorial waters, ${ }^{84}$ over which the UK exercises sovereign rights of exploration and exploitation.

\section{The Principle of Derivation}

Flowing from the provisions of the extant laws on the ownership and control of natural resources in Nigeria is the development and emergence of case law. The Nigerian Supreme Court in the case of Attorney-General of the Federation v. Attorney-General, Abia State (No. 2), ${ }^{85}$ held inter alia, that the federal government alone and not the littoral states can lawfully exercise legislative, exclusive and judicial powers over the maritime belt or territorial waters and sovereign rights over the Exclusive Economic Zone subject to universally recognized rights. ${ }^{86}$ According to the Supreme Court, the ownership, control and management rights over the natural resources located in the offshore areas of Nigeria is the exclusive preserve of the Federal Government of Nigeria to the exclusion of the federating units and the mere fact that oil rigs bear the names of indigenous communities on the coastline adjacent to such off-shore area does not prove ownership of such off-shore areas. ${ }^{87}$ This case brought to the fore the controversy between the federal and state governments over revenue allocation, popularly known as "the principle of derivation" which is a constitutional mechanism established by the federal government "to compensate for the minerals that are being extracted from states in which the minerals are found". According to Mudiaga Odje, the principle of derivation "is a constitutional directive which constitutes a form of reparation for an expropriated interest and cannot be waived or derogated from by either the state or federal government". ${ }^{88}$ The principle is the mechanism for revenue allocation under the Constitution of the Federal Republic of Nigeria 1999 (as amended). The rationale behind this mechanism is the need to utilise part of the total revenue from oil and gas accruing to the Federation Account in favour of the littoral states to help them use the money in tackling the ecological and environmental damage caused in their communities as a result of oil prospecting and hydrocarbon operations. The mechanism under the 1960 Constitution of Nigeria was 100 per cent, later reduced to 50 per cent under the 1963 Constitution, but now not less than 13 percent in the 1999 Constitution. The present 13 per cent has been greatly eroded by declining crude oil prices, economic recession and monumental corruption in the oil industry in Nigeria. This equally has affected the fortunes of the littoral states which cannot in the present situation of things "meet up with their obligations and this became the turning point for their agitation for resource control [and] ownership".

Writing on revenue allocation and resource control in the Nigerian Federation, a public affairs commentator has observed as follows: ${ }^{89}$

The controversy between the federal and state governments over revenue mobilization and allocation has assumed monumental proportion with the state governments now asserting the right of control over natural resources within their state boundaries and also calling for devolution of powers to the states beyond those provided for in the 1999 Constitution. The federal government took a pre-emptive legal action in mid February 2001 by filing a suit

\footnotetext{
82 AR Thompson, 'Resource Rights' (2006). Historical Canada available at http://www.thecanadian encyclopedian.ca (accessed on May 3, 2017).

83 See. Wikipedia, 'Geography of the United Kingdom', available at https://www.en.wikipedia.org (accessed May 3, 2017).

84 Twelve mile limit.

85 (2002) 6 NWLR (pt. 764) 542.

86 Ibid.

87 Ibid.

88 A Mudiaga Odje, True Federalism and Resource Control in Nigeria (2002) Quadro Impressions Ltd at 370.

89 RC Nwokedi, Revenue Allocation and Resource Control in Nigerian Federation (2001) Snaap Press Ltd, Enugu, at 123-126.
} 
against the 36 state governments in the Supreme Court over the subject of resource control and offshore oil claims. This singular federal government's action immediately escalated the issue of resource control into a major constitutional and political confrontation between the two body - politic.... Their action has further heightened the tension being generated over state claims over resource control and revenue derivation and the uncompromising posture of the federal government coupled with its lukewarm approach towards institutionalizing an acceptable revenue allocation formula. ${ }^{90}$

Nwokedi further argued that though the 1999 Constitution is ambiguous on the question of derivation principle as applicable on off-shore mineral resources, informed legal expert opinion tend to imply that the provisions of Act 9 of 1999 allowed some revenue to accrue to littoral states from off-shore mineral operation. The Act referred to as Deep Off-shore and Inland Basin Production Sharing Contracts Act, as it then stood, recognized that compensation was due to the littoral derivation states for deep off-shore and inland basin oil exploration. However, the question of whether or not littoral states are entitled to revenue derived from off-shore mining operations was a subject of litigation in the Supreme Court between the federal and the state governments. Notwithstanding the judicial decision on the subject, the controversy over off-shore mineral resources and resource control will never be settled amicably and satisfactorily unless through a political or constitutional process preferably through a national conference. Meanwhile the controversy rages on... ${ }^{91}$

This article argues that what gave rise to the upsurge of the demand for resource control by some states was their frustration over the existing revenue allocation system and the failure on the part of the federal government to institutionalize an acceptable revenue sharing formula. In addition, to adopt an effective legal and administrative mechanism to ensure fiscal autonomy for the federating states which will enable them to exercise adequately their constitutional and statutory responsibilities to their people. That system must of necessity, give adequate recognition to the right of each state to enjoy substantial proportion of revenue accruing to it from their natural resources and a measure of control or participation in the exploitation of natural resources within its geographical boundaries. It should be clear to the federal authorities that the constitution is the supreme law of the land and no one has the right to alter or suppress its application. The states should, in a true federalism, be entitled not only to their constitutional and legitimate shares of the federally collected revenues as and when due but also a considerable measure of control over their revenue resources. This is an important attributes of a federal system. A case in point is in the U.S.A where the state of Wyoming is currently reaping the full benefits of its resource control of oil. Before the then upswing in energy prices, the state was experiencing great depression with budget shortfall of $\$ 183$ million, which later rose to $\$ 700$ million surplus, due to the then rise in natural gas prices. Yet the U.S. federal government did not and could not interfere with the state's earnings or prescribe how the excess oil revenue must be spent. In Spain, which is not even a federation, considerable measure of autonomy over resource control was granted to the Basque region, which has been fighting for secession or separate identity. The same is true of the Province of Quebec in the Dominion of Canada where, the province was granted substantial autonomy in the management of its resources and internal affairs to discourage it from seceding from Canada. In Switzerland, the federating states called "the cantons" are so autonomous not only in self- government but also in the control of their natural resources that one could easily refer to Switzerland as a confederation of quasi-independent states. The political arrangement in that country is such that even the office of the President of the Republic rotates amongst the cantons so as to ensure equality, equity and freedom of association amongst the federating states. Decentralization or devolution of political and economic powers is a common attribute of other successful federations in Latin America, Europe and Asia. Nigerian federation should not therefore be an exception. ${ }^{92}$

However, because of Nigeria's peculiar political and constitutional history, it is important to organize a national conference of the various ethnic nationalities to work out a suitable constitutional framework for devolution of powers to the federating states. Meanwhile, it is suggested as a way to dampen the demand for reasonable control by some states, to involve the states in which oil or other mineral resources are located, in a partnership arrangement with the expatriate oil or mining companies. Ideally, it should be a tripartite joint ownership agreement between the foreign company, the federal and the state governments with each having its equity contribution, share and other stakes in the operation of the company. The dividends earned by the states from their equity holdings as well as their participation or involvement in the major policy decisions of the operations

\footnotetext{
Ibid.

Nwokedi, ibid.

Nwokedi, ibid.
} 
of the company would ameliorate their grievances of marginalisation and exploitation by both the foreign oil/mining companies and the federal government. It is only when this arrangement is complimented with a fair and equitable revenue allocation formula that would emphasise the derivative principle that the political tensions over the issues of derivation and resource control will be effectively contained and the spirit of federalism will be rekindled in Nigeria." ${ }^{93}$

The principle of derivation, particularly as it relates to the revenue accruing to the Federation Account directly from any natural resources is contained in section 162, sub-section (2) of the Constitution of the Federal Republic of Nigeria 1999 (as amended) which empowers the National Assembly to determine the formula for the distribution of funds into the Federation Account. It provides:

The President, upon the receipt of advice from the Revenue Mobilisation Allocation and Fiscal Commission, shall table before the National Assembly proposals for revenue allocation from the Federation Account, and in determining the formula, the National Assembly shall take into account, the allocation principles especially those of population, equality of States, internal revenue generation, land mass, terrain as well as population density: provided that the principle of derivation shall be constantly reflected in any approved formula as being not less than thirteen per cent of the revenue accruing to the Federation Account directly from any natural resources. ${ }^{94}$

By this principle "not less than thirteen per cent" of the revenue accruing to the Federation Account directly from any natural resources shall be payable to a State of the Federation from which such natural resources are derived. For a state to qualify for this allocation of funds from the Federation Account, the natural resources must have come from within the boundaries of the state, that is, the resources must be located within that state. ${ }^{95}$

To give effect to the content of section 162 (2) of the Constitution is the Allocation of Revenue (Federation Account, etc.) Act ${ }^{96}$ which is the statutory backing for the 13 per cent derivation as provided under section 162 (2). It is the constitutional mechanism "through which approved appropriations are" distributed among the federal, states and local governments. ${ }^{97}$ According to Mudiaga Odje, Nigeria's National Assembly contrary to section 162(2) of the Constitution has failed to "enact a new Revenue Allocation Act, under the 1999 Constitution, it is Act 106 of the 1992 a Decree deemed to be an existing Act under section 315, that was restyled as an Act by erstwhile President Olusegun Obasanjo in May 2002, that is still being applied as the Revenue Allocation Act since 29th May 1999 till date". ${ }^{98}$ This article argues that the 13 per cent derivation can be increased by an Act of the National Assembly of the Federal Republic of Nigeria without resort to a constitutional amendment. ${ }^{99}$ This is so, because the process of enacting an Act of the National Assembly is less rigorous and cumbersome, than that of amending the constitution..$^{100}$

Section 162(2) of the constitution provides for "...not less than 13 per cent...", which implies that 13 per cent represent the minimum but which can be increased by an Act of the National Assembly. Increasing the 13 per cent derivation principle is most likely to douse the militant attacks on oil and hydrocarbon installations in the Niger Delta area of Nigeria which has practically crippled hydrocarbon operations which in turn has led to drastic fall in Nigeria's crude oil and natural gas output in recent years. The need to review the 13 per cent derivation principle finds support and authority in section 32 (b), Item $\mathrm{f}$ of the amended 1999 Constitution which states that the Revenue Mobilization, Allocation and Fiscal Commission (RMAFC) shall "... review from time to time, the revenue allocation formula and principles in operation to ensure conformity with changing realities..." According to Mudiaga Odje, "for the principle of derivation, to have its desired effect, same must actually and eventually restore the owners of the expropriated resources back to their viable economic status before the "Unjustified Acquisition" of their interest, rights and resources by the Nigerian State". ${ }^{101}$

\footnotetext{
Ibid at $126-140$.

Section 162 (2) Constitution of the Federal Republic of Nigeria, 1999 (as amended).

Per Ogundare, JSC at para. 579A - TT, ibid.

1992, No. 106. S. I. 9 of 2002.

See the case of A.-G., Bendel State v. A.-G., Federation and Others, (1981) 3 NCLR 1, on the principle of derivation and the Allocation of Revenue (Federation Account, etc.) Act, ibid.

98 A Mudiaga Odje, '13\% Derivation, Falling Crude Oil Price and the Constitution (2016). Vanguard, 18 February 2016 at vanguardngv.com.

99 See the case of Attorney-General of the Federation v. Attorney-General of Abia State \& 35 Ors (No. 2), (2002) 6 NWLR (Part 764$) 542$.

100 See section 9, Constitution of the Federal Republic of Nigeria 1999 (as amended) on the mode of altering provisions of the constitution.

101 Footnote 98, above.
} 


\section{The Case of Attorney-General of the Federation v. Attorney-General of Abia State and 35 Others}

With this background, it is now intended to examine the landmark decision of the Supreme Court of Nigeria in the case of Attorney General of the Federation v. Attorney General of Abia State (No. 2). ${ }^{102}$

The gravamen of the case is resource control rights concerning whether ownership right and control of mineral resources located off-shore of the eight littoral states of Akwa Ibom, Bayelsa, Cross River, Delta, Edo, Lagos, Ondo and Rivers vest in the littoral states or the Federal Government of Nigeria. The Supreme Court stated that by virtue of section 44 (3) of the Constitution of the Federal Republic of Nigeria, the Federal Government has exclusive resource control and ownership rights over such mineral resources. The case also raised the issue of the principle of derivation, particularly as it relates to the revenue accruing to the Federation Account directly from any natural resources of which section 162 subsection(2) of the Constitution of the Federal Republic of Nigeria 1999 empowers the National Assembly to determine the formula for the distribution of funds into the Federation Account.

The facts of the case are as follows, the plaintiff by a writ of summons filed at the Supreme Court pursuant to the provisions of section 232(1) of the 1999 constitution sought reliefs against the defendants particularly against the eight littoral states of Akwa Ibom, Bayelsa, Cross River, Delta, Lagos, Ogun, Ondo and Rivers jointly and severally for a determination by the Supreme Court of the seaward boundary of littoral states within the Federal Republic of Nigeria for the purposes of calculating the amount of revenue accruing to the Federation Account directly from any natural resources derived from that state pursuant to section 162(2) of the constitution of the Federal Republic of Nigeria. The proviso to section 162 (2) of the 1999 constitution requires that any approved formula for revenue allocation from the Federation Account shall reflect the fact that not less than $13 \%$ of revenue accruing to the said Federation Account from any natural resources are allocated to the government of the state or territory where such resources are located. It therefore, becomes necessary for each of the persons or authorities concerned in the distribution of moneys in the Federation Account to ascertain precisely the natural resources located in each of the states of the federation. It must be ascertained the extent to which natural resources located on coastal land and adjoining sea/seabed ought to be treated as being located in the littoral or maritime state, which borders it. From the pleadings-the plaintiff's statement of claim, statements of defence and counter - claim by some (not all) the defendants, it was clear that the majority of the States as well as the federal government are of the opinion that none of the states can claim that natural resources on coastal land outside the low water mark or (if the case so requires) the seaward limit of inland waters are located within its territory. Since all the littoral / maritime states to wit: Akwa-Ibom, Bayelsa, Cross-Rivers, Delta, Lagos, Ogun, Ondo and Rivers hold the contrary view, the action herein was to determine this controversy. The pleadings of the plaintiff and the eight littoral defendant states showed their respective stands in the dispute. Some of the defendant states raised preliminary objections as to the absence of any dispute, misjoinder and lack of jurisdiction on the part of the Supreme Court to determine the matter. Some of these points were taken care of during the ruling on the preliminary objections raised by some of the defendant states and was effectively disposed of in the case of Attorney-General of the Federation v. Attorney - General of Abia State \& 35 Ors. (No. 1) ${ }^{103}$ The plaintiff's contended that the territory of a state in Nigeria extends to all areas over which a local government council within that state has power to administer and to make byelaws. In other words, the territory of a state is exactly co-extensive with the totality of the local government areas within its territory. The following statutes were cited for consideration by the Supreme Court, sections 3, 4, 232 (1), 162 (1), (2), (3) 153 (1) (n), and 315 of the 1999 constitution, the Territorial Waters Act, ${ }^{104}$ the Petroleum Act, ${ }^{105}$ the Sea Fisheries Act, ${ }^{106}$ and the Exclusive Economic Zone Act, ${ }^{107}$ all Laws of the Federation of Nigeria, 2004.

The Supreme Court stated, rightly it is submitted that the above enactments must be treated as valid until a court of law decides otherwise. It further stated that the scope, content and extent of all these enactments, is that the territorial waters of the Federal Republic of Nigeria commence from the low water mark along the coast and the

102 (2002) 96 LRCN, 559; (2002) 6 NWLR (Part 764), 542 - 905; AG Fed. v. AG Abia State \& 35 Ors. (2001) 11 NWLR, (Part 725). 689; (2001) 89 LRCN, 2413.

$103 \quad$ (2001) 11 NWLR 689.

104 Cap. 5, Laws of the Federation of Nigeria (LFN) 2004.

105 Cap. P10 LFN 2004.

106 CAP S4 LFN 2004.

107 Cap E17 LFN 2004. 
seaward limits of inland waters. ${ }^{108}$ The following defendant states - Akwa-Ibom, Bayelsa, Bornu, Cross-River, Delta, Gombe, Jigawa, Lagos, Ondo, Rivers and Sokoto states filed counter-claims to the action. The Supreme Court considered the competence or otherwise of the counter claims and the legal issues raised therein, ${ }^{109}$ and granted in part the counter-claims of the defendant states and declared certain policies and or practices of the plaintiff unconstitutional and in conflict with the provisions of the constitution and to that extent are void. ${ }^{110}$ The Supreme Court also granted an injunction restraining the plaintiff from further violating the constitution in the manner declared in the claim of the 10th defendant (Delta State).

The Supreme Court in its judgment considered the following municipal and international legislations - the 1999 constitution, sections 3, 314, 318 (4); The Northern Region, Western Region and Eastern Region (Definition of Boundaries) Proclamation, ${ }^{111}$ Allocation of Revenue (Federation Account etc.) (Amendment) Decree; ${ }^{112}$ Exclusive Economic Zone Act, ${ }^{113}$ General Loan and Stock Act, ${ }^{114}$ Interpretation Act; ${ }^{115}$ Niger Delta Development Act; ${ }^{116}$ Off-shore Oil Revenue (Registration of Grant) Act; ${ }^{117}$ Petroleum Act; ${ }^{118}$ Sea Fisheries Act, ${ }^{119}$ and Territorial Waters Act. ${ }^{120}$ Geneva Convention on the Territorial Sea and the Contiguous Zone; ${ }^{121}$ United Nations Convention on the Law of the Sea. ${ }^{122}$ Geneva Convention on the Continental Shelf, ${ }^{123}$ and the Geneva Convention on the High Seas. ${ }^{124}$ It also considered and reviewed several judicial decisions, particularly the cases of R. v. Keyn ${ }^{125}$ Reference Ownership of Offshore Mineral Rights ${ }^{126}$ and New South Wales \& Ors. v. Commonwealth $^{127}$ and held inter alia, that the sea is the southern boundaries of the eight littoral states. His Lordship, Ogundare J.S.C. (as he then was) delivering the lead judgment stated as follows:

With this conclusion, I hold and determine, that the seaward boundary of a littoral state within the Federal Republic of Nigeria for the purpose of calculating the amount of revenue accruing to the Federation Account directly from any natural resources derived from that state pursuant to section 162 (2) of the Constitution of the Federal Republic of Nigeria 1999 is the low-water mark of the land surface thereof or (if the case so requires as in the Cross River State with an archipelago of islands) the seaward limits of inland waters within the State. And this shall be my judgment in respect of the plaintiff's case.

It was argued by some of the defendants that if the boundary of Nigeria under international law extends to the sea, that is the territorial sea or the contiguous zone or continental shelf or to whatever extent, then, that is the same as the boundary of any littoral state. The defendants anchored this submission on the learned Chief Justice

108 See, R. v. Keyn (1876) 2 CD 63 at 67; The Mecca (1895) 95 at 107; A-G. of Southern Nigeria v. JohnHolts \& Co. (Liverpool) Ltd. \& Ors. (1915) AC 599; 2 NLR, Full Court (Common Law); U.S. v. Louisiana L.ed, 1025 (USA); Abuakwa v. Adanse (1957) 3 All ER 559; Amon v. Tuck (1956) 1QBD 357; Atta II v. Agyei (1952) 14 WACA 149; Tella v. Akere (1958) WRNLR 26; Peenok v. Hotel Presidential (1983) 4 NCLR 122; PDP v. INEC (1999) 71 LRCN 2464; (1999) 11 NWLR (Pt. 626) 200; Okechukwu v. Okafor (1961) 2SCNLR 369; Otanioku v. Mustafa (1977) 11-12S.C.9.

109 See, Green v. Green (1987) 18 NSCC (Pt. 2) 1115, I.B.W.A. v. Imano (2001) 3 SCNJ 160; Itauma v. Akpe - Ime (2000) 80 LRCN 2480; (2000) 12 NWLR (Pt. 680) 56; Obulor v. Obiora (2001) 4 SCNJ 22; Lordye v. Ihyambe (2000) 15 NWLR (Pt. 92) 675; Odonigi .v. Oyeleke (2001) 6 NWLR (Pt. 708) 12; Ifezue v. Mbadugha (1984) 5 S.C. 79.

110 See .A.-G. Bendel State v. A.G. Federation (1983) ANLR 208 A.G. Bendel State v. A--G Federation (1981) 10 S.C.1; A.-G. Ogun State v. A.-G. Federation (1982) 1-2 SC, 13; Afolayan v. Ogunrinde (1990) I NWLR (Pt. 127) 369; A.G. v. Mclver \& Co. 2 N.L.R 1; Amachree v. Kalio 10 NLR 108; Ayoke v. Bello (1992) NWLR (Pt. 218) 380; Balewa v. Doherty (1963) W.L.R. 949; Braide v. Adoki, 1.0 NLR 15.

$$
1954 .
$$


of the Federation (Uwais, CJN) dictum in the case of $A G$ of the Federation v. AG of Abia State \& 35 Ors. (No. 1) ${ }^{128}$ where he stated in the following terms:

There cannot be a boundary dispute between the Federation, which consists of all the states of the Federation, and individual states whether littoral or otherwise since the boundaries are the same, see section 2 subsection (2) of the constitution which provides that "Nigeria shall be a Federation consisting of states and a Federal Capital Territory.

In response on whether the case of $A G$ of the Federation v. AG of Abia State \& 35 Ors. (No. 1) ${ }^{129}$ is authority for the view that if Nigeria's boundary under international law extends to the sea, same also represents the boundary of any littoral State, Uwais, C.J.N. stated as follows:

With respect, this argument cannot be correct. My dictum above, on a careful examination, is tied down to the provisions of section 2 subsection (2) of the 1999 constitution, and not the issue of territorial waters which is a subject of international law. ${ }^{130}$

The learned Chief Justice of Nigeria, further referred to Articles 2 and 3 of Part II of the United Nations Convention on the Law of the Sea (UNCLOS) 1982 on Territorial Sea and Contiguous Zone which extends the sovereignty of a coastal state beyond its land territory and internal waters. By Article 3, every state has the right to establish the breadth of its territorial sea up to a limit not exceeding 12 nautical miles, measured from baseline determined in accordance with UNCLOS. The case of Queen v. Keyn ${ }^{131}$ was referred to. It should be noted that the 3 nautical miles mentioned in the case were later extended to 12 nautical miles by the 1958 Geneva Convention on the Territorial Sea and the Contiguous Zone, which preceded the 1982 United Nations Convention on the Law of the Sea. The 1982 United Nations Convention on the Law of the Sea is a comprehensive treaty on the Sea. It supersedes the 1958 Conventions. The position of the law was further stated by Uwais, CJN as follows:

What the Federation has over the territorial waters and air space is the power to exercise sovereignty over the territorial waters and air space and not that they constitute extension of the boundary of Nigeria or indeed the littoral states.

... On the whole there is no law which I am aware of which has extended the littoral boundary of Nigeria from that defined by the 1954 Proclamation. None of the defendants has cited any law which has extended the seaward boundary of Nigeria, beyond that defined by the Proclamation. ${ }^{132}$

On ownership of the land and sea, hence the natural resources found within them, the Supreme Court was of the opinion that the Convention of the High Seas debunked the claims of the littoral defendant states to ownership of the land and sea far beyond the territorial sea. It stated that the Convention on the Territorial Sea and the Contiguous Zone grants only limited sovereignty to coastal states over their territorial seas. It is unlike the sovereignty such states have over their land territory.

The Supreme Court stated thus:

To the extent that the Littoral Defendant States seek, by affidavit evidence, to prove that these areas of the sea belonged in the past to communities indigenous to these states, I hold that such evidence is nebulous. It falls far short of the nature and quality of the evidence required in a case like this where the claim of the indigenous community to ownership of the sea runs against the grain of statutory instruments (Orders in -Council) and the common law and international law, too. It is not the case of the littoral defendant states that, like the original American States, the crown made a grant of the off-shore to them or their predecessors in title (that is, the Eastern and Western Regions of Nigeria or the Colony and Protectorate of Southern Nigeria). The mere fact that oil rigs and or wells located in the off-shore areas bear names of indigenous communities on the coastline adjacent to such offshore areas is of no moment in proving ownership to such off-shore areas. Such naming, as well as provisions in the various Acts for registration, etc. to be in the states adjacent to these areas, is only an

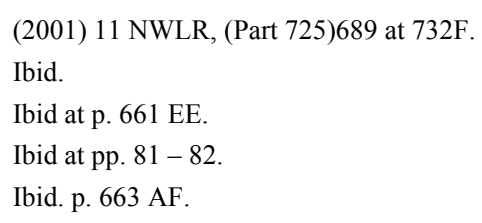


internal administrative arrangement made by the plaintiff. ${ }^{133}$

It also relied on and applied the following cases - The Mecca $;{ }^{134}$ R. v. Liverpool Justices, exp. Molyneux; ${ }^{135}$ Attorney - General Southern Nigeria v. John Holts; ${ }^{136}$ U.S. v. Louisiana $;{ }^{137}$ Reference Re Ownership of Offshore Mineral Rights ${ }^{138}$ and New South Wales \& Ors. v. Commonwealth. ${ }^{139}$ The Supreme Court held that the principles of the common law and international law pronounced in those cases are applicable to this case. Thus, it held that at common law, the boundary mark between a riparian owner, such as the littoral states are, in this case, is the sea, and the sea is the low water mark. ${ }^{140}$ The reliance placed by the Supreme Court on the common law and its cases, particularly R. v. Keyn ${ }^{141}$ has attracted harsh criticism from a learned constitutional lawyer and learned Senior Advocate of Nigeria, Professor Itse Sagay. The learned Professor argues that the Supreme Court with greatest respect erred in going on a voyage of discovery to rely on an old English criminal case decided at common law and which has been overruled by a recent legislation which repealed the statute and or principles upon which R. v. Keyn ${ }^{142}$ was decided. This was also the view of some of the defendants who argued that the common law is not applicable. To the learned Professor and some of the defendants' argument, the Supreme Court as per Ogundare, J.S.C., had this to say:

I cannot accept this submission, Common Law has been received law in this country since 1863 when it was applied to Lagos and 1914 when by the Supreme Court Ordinance of that year, it was applied to the Colony and Protectorate of Nigeria. In Charlie King Amachree v. Daniel Kalio, ${ }^{143}$ John Holts case (supra) and Chief Braide v. Chief Adoki, ${ }^{144}$ to mention a few, common law was applied to resolve the issues arising in those cases. I do not think I need say more on this except to point out that the successor to the British Crown is the Government of the Federation of Nigeria.

The Supreme Court's reasoning is sound and this article agrees with it. Where the sea is a boundary, the boundary - mark is the low- watermark. The low-water mark, therefore, forms the boundary of the land territory of, not only the eight littoral States of Nigeria, but of Nigeria as well.

In further response to the argument that a later legislation overruled R. v. Keyn, ${ }^{145}$ His Lordship said:

Contrary to the submission of learned Attorney General of Cross-River State (9th Defendant), the Territorial Jurisdiction Act 1879 was enacted in the United Kingdom not with a view to overruling, by legislation, the Courts decision in R. v. Keyn (supra), but to give effect to the growing notion of territorial waters and the exercise of criminal jurisdiction within them. ${ }^{146}$

It is clear from the judgment of the Supreme Court and the case of $R$. v. Keyn ${ }^{147}$ that for a proper determination of criminal and civil liability under the various environmental legislations in Nigeria, particularly the Harmful Waste (Special Criminal Provisions etc.) Act ${ }^{148}$ and the NESREA Act, ${ }^{149}$ this case is a relevant legal authority. This is so, because to determine criminal or civil liability for various environmental offences contained therein, it is necessary to ascertain from the provisions of the Territorial Waters Act, Sea Fisheries Act and Exclusive Economic Act, the jurisdiction of the place where the offence was committed so as to ascertain whether it falls

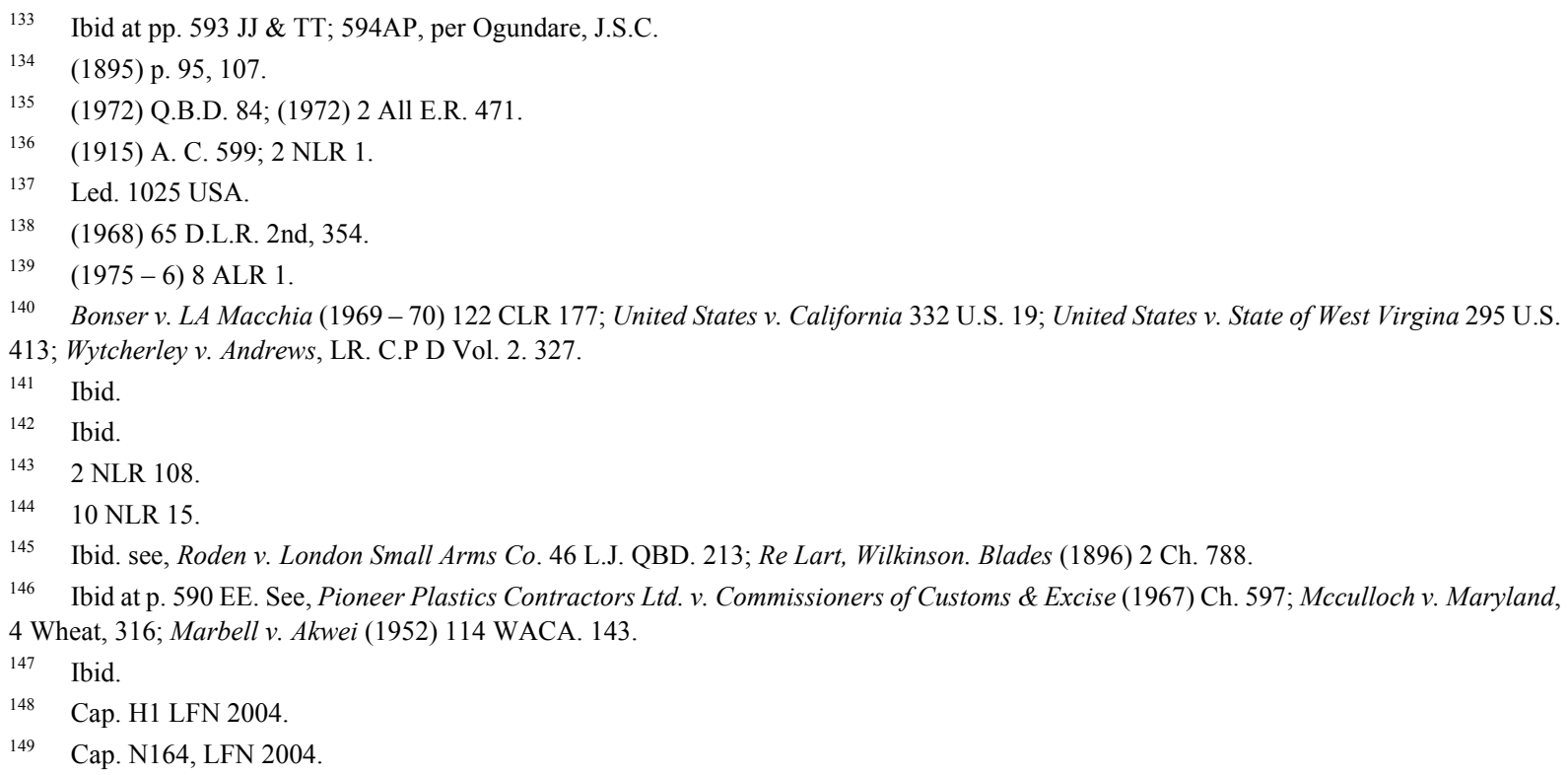


within the prohibited zone or the Exclusive Economic Zone or the territorial waters or the inland waterways. Then and only then could the courts exercise criminal or civil jurisdiction within them. All these issues were canvassed and decided on by the Supreme Court. For instance, Territorial Waters Act is inter alia concerned with jurisdiction in respect of offences, committed in the territorial waters and restriction on Nigerian courts from trying persons other than Nigerian citizens for offences committed in territorial waters. Similarly, the Sea Fisheries Act is concerned with the control, regulation and protection of sea fisheries in the territorial waters of Nigeria. The same applies to the Exclusive Economic Zone Act which is a legislation on exercise of sovereign right by Nigeria in relation to the conservation or exploitation of the natural resources of the seabed, its subsoil and superjacent waters etc. within the territorial waters.

The case illustrates the use of the public trust doctrine for environmental conservation in litigation. The Supreme Court relied upon the English common law as exemplified by the case of R. v. Keyn ${ }^{150}$ and the provisions of the 1999 constitution which vests exclusive control of the country's natural resources on the federal government for the benefit of the citizens. The case reaffirms the overbearing nature of the federal financial power over the states. It however redressed some imbalance and inequities in the sharing of the revenue accruing into the Federation Account. By this singular decision, the Supreme Court have restated the need for the practice of true federalism by the federal government. An interesting aspect of the case is that all the learned counsel for the defendants who appeared in the case, relied more on the municipal laws than on international treaties. For instance, there was no vigorous attempt by the learned counsel to address the apex court on United Nations Convention on the Law of the Sea 1982 nor on the 1958 Convention on the Continental Shelf. This grave error or oversight must have affected the judicial reasoning of the apex court, which relied heavily on the English common law principles and the international treaties and conventions in arriving at their decision. This is natural, because the Supreme Court cannot go outside the facts presented it by the parties. It cannot do the defendants' case for them, so it based its decision on materials and submissions made available to it by learned counsel for the Defendants and that of the plaintiff.

The case brought to the fore "the power play over money"151 and the political imperative of revenue sharing formula of the country's financial income. What the Supreme Court did was to state the law and apply the same to the facts available to it, it nevertheless, with greatest respect failed to pronounce on new formula for sharing the country's resources, apart from the fact that it restated the existing law on the subject, that is the principle adopted by the military. The Supreme Court thus lost the opportunity to review the existing formula "which was seen as being too lavish on the Federal Government". ${ }^{152}$ It appears however, that that discretion is not for the court to exercise as its power is limited to what is provided in the constitution, otherwise it would lead to what the Supreme Court called judicial legislation, which the courts should avoid. Kutigi, J.S.C. put it more aptly when he stated the principle:-

...That would in my view be tantamount to judicial legislation. That is not allowed. This court has no legislative powers and it cannot rewrite the laws. Only the legislature can lawfully and properly do that if it so wishes. ${ }^{153}$

\section{What Constitutes Continental Shelf}

It is intended to chip in a word here on what constitutes continental shelf. This is necessary as the term featured prominently in the 1960 and 1963 constitutions. It also arose conspicuously in the Resource Control Case (No. 2). ${ }^{154}$

"Continental shelf" is nowhere found or defined in the 1999 constitution, so it becomes imperative to have resort to the relevant international legislation in this regard of which Nigeria is a party and signatory to, having ratified the said treaty and or Convention, ${ }^{155}$ Part VI of the United Nations Convention on the Law of the Sea (UNCLOS), 1982 deals with the continental shelf.

\footnotetext{
$150 \quad$ Ibid.

151 See, E Aziken, 'The Power Play Over Money'. The Magazine section of Sunday Vanguard, August 11, 2002, vol. 23 No. 10673 - pp. 14, 15. The questions which percentage each tier of government - Federal, State and Local Government gets is a political one which is not justiciable as a direct legal issue - per Uwaifo. J.S.C., in A-G. Abia State v. A-G. Federation [2003] 4 N.W.L.R Part 809.124 at p. 231 paras B-D.

152 Ibid p 14.

153 Ibid at pp. 720TT and $721 \mathrm{AF}$.

154 Ibid.

155 The United Nations Convention on the Law of the Sea 1982, which is in force in Nigeria and is published in Nigeria's Treaties in Force 1970 - 1990, by the Federal Ministry of Justice, Volume 2.
} 
Article 76 of the Convention defines a continental shelf to mean:

The continental shelf of a coastal state comprises the seabed and subsoil of the submarine areas that extend beyond its territorial sea throughout the natural prolongation of its land territory to the outer edge of the continental margin, or to a distance of 200 nautical miles from the baseline from which the breadth of the territorial sea is measured where the outer edge of the continental margin does not extend up to that distance. ${ }^{156}$

Articles 77 and 78 appearing hereunder defines and provides for the rights of a coastal state over its continental shelf as well as the limitation of those rights -

Article 77 - Rights of the coastal State over the Continental Shelf.

(1) The coastal state exercises over the continental shelf sovereign rights for the purpose of exploring it and exploiting its natural resources.

(2) The rights referred to in paragraph 1 are exclusive in the sense that if the coastal state does not explore the continental shelf or exploit its natural resources, no one may undertake these activities without the express consent of the coastal state.

(3) The rights of the coastal state over the continental shelf do not depend on occupation, effective or notional, or on any express proclamation.

(4) The natural resources referred to in this part consist of the mineral and other non-living resources of the sea-bed and subsoil together with living organism belonging to sedantry species, that is to say, organisms which, at the harvestable stage, either are immobile on or under the sea-bed or are unable to move except in constant physical contact with the sea-bed or the subsoil. ${ }^{157}$

Article 78 - Legal status of the superjacent waters and air space and the rights and freedoms of other states.

(1) The rights of the coastal state over the continental shelf do not affect the legal status of the superjacent waters or of the air space above those waters.

(2) The exercise of the rights of the coastal state over the continental shelf must not infringe or result in any unjustifiable interference with navigation and other rights and freedom of other states as provided for in this Convention."158

The UNCLOS gives the coastal state of which Nigeria is one, limited sovereign right over the continental shelf. "It can be seen from above that though a coastal state exercises certain sovereign rights over its continental shelf, that does not make the shelf part of her land territory over which she has absolute and exclusive control; her sovereign right over the continental shelf is of a limited kind only". ${ }^{59}$

"Coastal State" in the Convention means "Nation State" and not internal states of a country, like the littoral states of Akwa-Ibom, Bayelsa, Cross-River, Delta, Lagos, Ogun, Ondo and Rivers state. In a federation, it applies to the federation and not the constituent or federating states that comprise the federation. This is necessarily so, because international law applies to countries that are members of the comity of Nations. The federation of Nigeria is such a country and the 1999 constitution affirms this by including "External Affairs" as item 26 in the Exclusive Legislative List. The 36 constituent states of Nigeria are not members of the comity of Nations and so the provisions of international law in a convention do not directly apply to them but the federation. ${ }^{160}$ This reasoning accords also with the rules of international law and the statement in the case of Queen v. Keyn ${ }^{161}$ which was adopted by the Supreme Court in holding that the southern boundaries of the littoral states (in the Resource Control Case (No.2) end at the low water mark along the coast. ${ }^{162}$

Despite the landmark pronouncements and decisions reached by the Supreme Court in its judgment in the case of Attorney - General of the Federation v. Attorney General of Abia State and 35 others, ${ }^{163}$ one can boldly submit

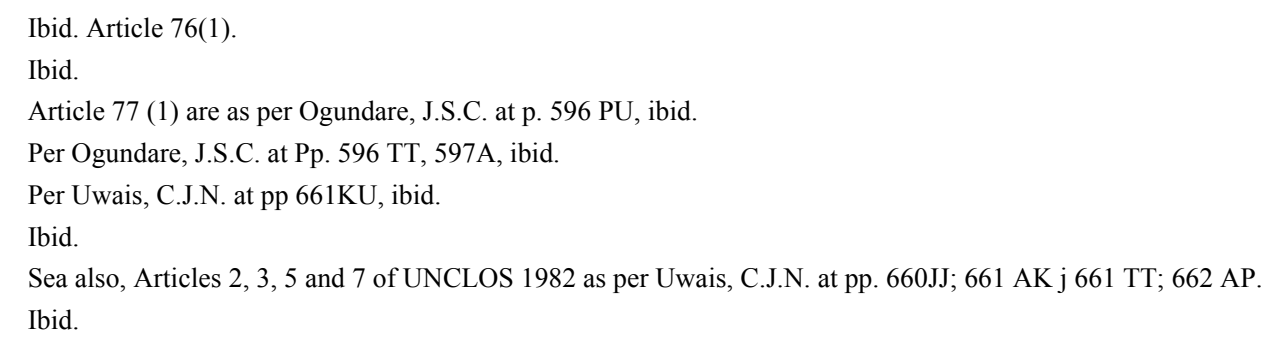


that with all its contradictions, the struggles over a popular revenue allocation formula have remained ever contentious. Though the Supreme Court has judicially determined the issue, the dispute between the parties as to who owns the natural resources derivable from Nigeria's territorial waters, continental shelf and the exclusive economic zone persists and has now been shifted to the "political court" of the citizens. The Supreme Court's judgment though final with due respect, has raised serious political issues and social conflicts within the Nigerian polity particularly among the eight littoral states. A long-term solution to the problem raised by the Supreme Court judgment is that a revenue allocation formula which should meet the yearnings of the people should be worked out and incorporated in the constitution. This entails specific constitutional amendment that will seek the introduction of a new section in the 1999 constitution. The new section must recognize and provide that the contiguous zone adjacent to a littoral State shall be deemed part of that State for determining its share of revenue on the basis of the derivation principle.

The natural resources found off-shore in the contiguous zone adjacent to any of the littoral states should be regarded as if found within the territory of that state for the purpose of determining its share of the revenue from those resources under the derivation principle. The federal government should be made to use a specified portion of its share of the Federation Account (five per centum) to take care of the degradation of the environment of the littoral States. This should be so as "oil money fuels federal - state power and activity in Nigeria."

\section{Implications for Environmental Law and Practice of Ownership and Control of Natural Resources}

The starting point here is the question of land ownership. Land includes mines and minerals, whether or not held apart from the surface. Land is not just the actual surface but also the land below and the airspace above. This is usually expressed by the Latin maxim cuius est solum eius est usque ad coelum et ad inferos (meaning he who owns the land owns everything reaching up to the very heavens and down to the very depths of the earth). This statement means that whoever has a legal estate in land owns not only the surface of that land, but also the airspace above the land to an unlimited extent and the land below also to an unlimited extent. ${ }^{164}$ This view raises the issue of the rights of landowners vis-à-vis the natural resources contained in them. ${ }^{165}$ This general proposition of the law has been modified by Nigeria's Land Use Act $1978,{ }^{166}$ which deals with the acquisition, use and enjoyment of land, and defines the extent of rights of individuals, private or public bodies and activities over land. All land in the state vests in the Governor of that state who shall ensure that land comprised within the state is used for the benefit and enjoyment of the citizens. Of course, under the Nigerian Law, while the Governor of a state "owns" all the land, this concept of ownership does not extend to "the... property in and control of all minerals, mineral oils and natural gas in, under or upon any land in Nigeria or in, under or upon territorial water and the Economic Zone of Nigeria [which] shall vest in the Government of the Federation and shall be managed in such manner as may be prescribed by the National Assembly". ${ }^{167}$ Thus, under the Nigerian law, ownership of land is vested in the state and that of natural resources on the federal government. The implication for the environment is therefore very obvious, in that the activities of the federal government and its agencies which create environmental problems, for example in oil and natural gas prospecting operations can only be controlled and remedied by them. This is so, because such mining and hydrocarbon activities are tied to state ownership of land in Nigeria and the activities carried on in the land usually raise environmental problems which impact negatively on the lives of citizens. Because land belongs to the state, environmental considerations and protection becomes the duty of the state. ${ }^{168}$ It is in this regard that the Nigerian state has attempted albeit, feebly to enact certain laws aimed at environmental protection. Furthermore, because land belongs to the state and all the natural resources contained in them, the federal government owns and manages the financial resources accruing from them, though as has been argued by many, to the disadvantage of the states. This has given rise to the agitation for resource control by the littoral states, which argue that because the federal government owns the natural resources extracted from their areas and controls the money accruing therefrom, they the littoral states remain in a very precarious financial position to tackle infrastructural deficits and the environmental problems created by the exploration, exploitation and extraction of these mineral resources located in their land.

The implications for environmental law and practice of ownership and control of natural resources under the

\footnotetext{
164 J Duddington, Land Law (2007, 2017). Sixth edition, Pearson Education Limited, Harlow, United Kingdom at 1.

165 Bocardo S.A. v. Star Energy UK Onshore Ltd. (2010) Ch. 100.

166 Cap. L5, Laws of the Federation of Nigeria, 2004.

167 Section 44 (3), Constitution of the Federal Republic of Nigeria 1999 (as amended).

168 Section 20, Constitution of the Federal Republic of Nigeria 1999 (as amended0 provides, 'The State shall protect and improve the environment and safeguard the water, air and land, forest and wildlife of Nigeria'.
} 
Nigerian Constitution 1999 is therefore, that the duty to "protect and improve the environment..." vests on the federal government of Nigeria. Natural resources activities, particularly oil exploration and production by the federal government owned agencies and the foreign oil companies have serious impact on the "natural environment". These activities involve projects that destroy the environment: land clearance for seismic lines which destroys flora and fauna and causes deforestation; establishment of seismic and drilling camps, infrastructure construction, and drilling for the oil. All these causes environmental problems ranging from deforestation, displacement of communities and persons from their ancestral land, oil spills, flaring of gas and "these activities and their effects leave an environmental footprint". The impact of hydrocarbon operations and crude oil exploration and production on vegetation, aquatic lives and public health, particularly in Ogoni land has been described as "been disastrous" ${ }_{169}$ The totality "environmental situation... needs urgent and focused attention". ${ }^{170}$ This is so, because the federal government who owns and controls natural resources in Nigeria has only paid lip service to solving the environmental problems created by their poor management of environmental issues arising from activities connected with hydrocarbon and crude oil operations in the country. Despite the plethora of environmental laws and regulations that abound, the country's environment has continued to be impacted by oil and gas flaring pollution and discharge of hazardous substances into the environment.

\section{Conclusion}

A cursory examination of the ownership and control of natural resources in the United States, Canada and United Kingdom has shown that only the later vests ownership and control of natural resources exclusively in the Crown. The United States and Canada, both with federal structure like Nigeria vests "ownership rights" in the federating units. They both also recognize and protect private ownership rights of natural resources. This article therefore, argues that the federal government of Nigeria should through the National Assembly follow the pattern in United States and Canada. This would stem the current tide of militancy, kidnapping and terrorist attacks on the oil companies, their staff, infrastructure and blowing up of oil and gas pipelines which has impacted adversely on the country's revenue and environment. The agitation by the littoral states of the Niger Delta of Nigeria for total ownership and control of the natural resources located within their area is legitimate and justified. The National Assembly should urgently review and revise all the relevant laws which vest ownership and control exclusively in the federal government, to empower the littoral states to own and control their natural resources. Private ownership of natural resources located in land belonging to individuals should be recognized and implemented.

Reason is the soul of law and when reason of any particular law ceases, so does the law itself. This is usually expressed in the Latin maxim cessant ratione legis cessat ipsa lex. Therefore, if the law of any place fails the test of "reason", that law loses its "soul"; and may likely lead to civil disobedience and crisis. This is the situation with the extant laws particularly the Constitution of the Federal Republic of Nigeria 1999 that vests ownership and control of natural resources located within the littoral states on the federal government. This law lacks "reason" and "soul" and must be revised in tandem with modern realities and demands of the society. The federal government should urgently revise and review all the extant laws on hydrocarbon operations and natural resources ownership and control to align with the dictates of the time. This remains the only permanent solution to the present agitation for "resource control".

However, this article argues that should the federal government feel otherwise, it must redefine the extent of natural resources rights and ownership as presently contained in the 1999 Constitution, to accommodate the legitimate expectation and desires of the littoral states. It has been suggested that "a legal title [shall confer] on the federal government and an equitable interest in the oil producing states and communities based principally on the concept of trust, which accommodates shared control and responsibilities". ${ }^{171}$ This article argues that as attractive as this suggestion by Aladeitan is, it is likely to create its own problems on the interpretation and application of "legal title", "equitable interest" and "trust". This raises the issue of "bundle of rights" and the complex legal issues of determining when an equitable interest may arise, and when a trust is established. Again equitable interest is a real right and not a legal right, therefore does not solve the problem of federal government's ownership and control of natural resources. This hybrid arrangement suggested by Aladeitan is therefore fraught with problems and may likely resurrect the common law problems of equitable and legal titles.

In the light of the above, this article argues and concludes that section 44 (3) and item 39 in the Second Schedule,

\footnotetext{
169 United Nations Environment Programme, Environmental Assessment of Ogoniland (2011). Nairobi, Kenya: United Nations Environment Programme at 158 , generally $152-200$.

170 Ibid at 205.

171 L Aladeitan, 'Ownership and Control of Oil, Gas, and Mineral Resources in Nigeria: Between Legality and Legitimacy' (2013). Thurgood Marshall Law Review, Vol. 38:159 at 194-197 at 197.
} 
Part I, Exclusive Legislative List, Constitution of the Federal Republic of Nigeria 1999 be expunged. Such other provisions contained in the Land Use Act, ${ }^{172}$ the Petroleum Act ${ }^{173}$ and the Nigerian Minerals and Mining Act, ${ }^{174}$ which vests ownership, "the entire property in and control of all minerals, mineral oils and natural gas in, under or upon any land in Nigeria or in, under or upon the territorial waters and the Exclusive Economic Zone of Nigeria" in the federal government to the exclusion of the littoral states, are exasperating, having no "reason" and "soul" and should also be revoked and annulled. These provisions are oppressive and "deprive the people [of the Niger Delta]" the enjoyment of ownership and control of their lands and natural resources. Having said this, the federal government should rise above primordial sentiments and summon the political will to amend the 1999 Constitution to allow the littoral states enjoy ownership of natural resources located in their areas. Private ownership of natural resources located in the land of individuals should be recognized. In turn the extant laws should provide and limit the role of federal government to issuing of oil prospecting, exploitation and production licences and entitlement to royalties from the littoral states and private owners of natural resources, with provisions on "certainty in the terms and conditions of exploration and development". In this way, the littoral states will be disposed and in a better position to tackle the problems of environmental degradation created by hydrocarbon operations. The revenues accruing from the natural resources to the littoral states would then be utilized to restore the environment, and this would be the panacea to the agitation for resource control and an end to the Niger Delta militancy.

72 Cap. L5 Laws of the Federation of Nigeria, 2004.

173 Cap. P10 Laws of the Federation of Nigeria, 2004.

174 Act No. 20. 